\title{
PENGARUH METODE PEMBELAJARAN KOOPERATIF DAN PENGUASAAN KOSAKATA TERHADAP PEMAHAMAN BACAAN BAHASA INGGRIS
}

\author{
Hilal Fathoni ${ }^{1}$ \\ Program Studi Pendidikan Bahasa Inggris \\ Fakultas Pascasarjana \\ Universitas Indraprasta PGRI \\ email: om.hila193@gmail.com ${ }^{1}$
}

\begin{abstract}
This study uses an experimental method, namely by giving different treatments to two student learning groups. The population in this study were private Madrasah Aliyah students in the district. Karawang in the 2019/2020 academic year totaling $\leq 500$ students. The results there are 1). There is a significant influence of cooperative learning methods on the English reading comprehension of private Madrasah Aliyah students in the district. Karawang. This is evidenced by the sig value of $0,000<0.05$, with $F_{\text {count }}=15.638 .2$ ). There is a significant influence in the mastery of vocabulary on the understanding of English reading of Madrasah Aliyah Private students in the district. Karawang. This evidenced by the sig value of $0.047<0.05$, with $F_{\text {count }}=4.058$. 3). There is a significant interactive influence on cooperative learning methods and vocabulary mastery of English students' reading comprehension of Madrasah Aliyah Private in the district. Karawang. This is evidenced by the sig value of $0.016<0.05$, with $\mathrm{F}_{\text {count }}=6.062$. The use of cooperative learning methods and the use of vocabulary can influence students' higher comprehension of English reading.
\end{abstract}

Keywords: cooperative learning method, vocabulary mastery, English reading comprehension

\section{Pendahuluan}

Menghadapi tantangan pendidikan, pengajaran di sekolah maupun di tingkat kuliah dituntut menghasilkan sumber daya manusia yang berkualitas. Sebagai contoh di kota Karawang, Karawang adalah kota pertanian karena menjadi lumbung padi di Provinsi Jawa Barat bahkan menjadi wilayah ketahanan pangan. Republik Indonesia. Namun, pada tahun 1993 Karawang dan sekitarnya telah diusung oleh Pemerintah selama enam periode penggantian Republik Indonesia untuk menjadi sebuah Kawasan Industri yang terbesar di Asia, dengan konsep Kawasan Industri tanpa polusi dan pengolahan limbah yang terpadu. Wilayah Karawang dan sekitarnya telah menjadi pusat investasi banyak developer dan dibangun kawasan industri besar baik dari Indonesia maupun dari Internasional. Dari tahun 1993 sampai sekarang, dan sejalan dengan eksistensi program pemerintah dari tahun 1993 hingga saat ini, Karawang telah menjadi suatu kawasan yang menopang penerimaan devisa negara terbesar di Indonesia dan telah ditetapkan oleh pemerintah menjadi Kawasan Ekonomi Nasional.

Dalam pembelajaran bahasa Inggris, diwajibkan menguasai empat kemampuan, yaitu listening (menyimak), speaking (berbicara), reading (membaca), dan writing (menulis). Membahas tentang reading (membaca). Banyak siswa di Karawang tingkat Madrasah Aliyah, terutama siswa kelas XI banyak ditemukan permasalahan dalam reading (membaca) terutama dalam hal reading comprehension (pemahaman membaca) yang membutuhkan pengetahuan baru, memahami konsep baru, atau menerapkan informasi teks dengan tepat. Ini adalah sebuah masalah yang disebabkan dari berbagai macam faktor. Salah satu masalah yang terkait dengan permasalahan metode pembelajaran atau pendekatan pembelajaran yang digunakan oleh guru dan siswanya terhadap penguasaan kosakata. Penguasaan kosakata penting untuk dapat menerjemahkan dan juga memahami isi dari bacaan tersebut.

Berdasarkan permasalahan di atas, kita dapat mengidentifikasi bahwa siswa Madrasah Aliyah (MA) di Karawang memiliki prestasi lemah terhadap pemahaman membaca. Oleh sebab itu diperlukan peningkatan kualitas pembelajaran terutama dalam pendekatan dan metode yang digunakan oleh guru 
terhadap kurangnya kosakata yang menjadi kekurangan siswa untuk dapat menerjemahkan dan memahami isi bacaan dengan mudah. Maka dari itu hal tersebut menjadikan alasan kenapa penulis melakukan penelitian ini:

1. Apakah terdapat pengaruh metode pembelajaran kooperatif terhadap pemahaman bacaan bahasa Inggris siswa MA Swasta di Kabupaten Karawang?

2. Apakah terdapat pengaruh penguasaan kosakata terhadap pemahaman bacaan bahasa Inggris siswa MA Swasta di Kabupaten Karawang?

3. Apakah terdapat pengaruh interaktif metode pembelajaran kooperatif dan penguasaan kosakata terhadap pemahaman bacaan bahasa Inggris siswa MA Swasta di Kabupaten Karawang?

\section{Metode}

Penelitian ini dilaksanakan di lingkungan MA Swasta di wilayah Kabupaten Karawang, Jawa Barat. Sedangkan objek penelitiannya adalah para siswa kelas X di MA Nihayatul Amal Rawamerta dan MA Al Kautsar, Cilamaya pada tahun akademik 2019/2020. Penelitian ini dilaksanakan pada bulan Oktober 2019 sampai Januari 2020.

Tabel 1

Desain Penelitian

\begin{tabular}{|l|c|c|}
\hline \multicolumn{1}{|c|}{ Pembelajaran Kooperatif } & $\begin{array}{c}\text { Think Pair Share } \\
\text { (A1) }\end{array}$ & $\begin{array}{c}\text { Jigsaw } \\
\text { (A2) }\end{array}$ \\
\hline Pemahaman Kosakata & A1B1 & A2B2 \\
\hline Pemahaman kosakata tinggi & A1B2 & A2B2 \\
\hline Pemahaman kosakata rendah & $\sum$ A & $\sum \mathrm{B}$ \\
\hline Notal &
\end{tabular}

Catatan:

A1 : Think Pair Share

A2 : Jigsaw

B1 : Pemahaman kosakata tinggi

B2 : Pemahaman kosakata rendah

A1B1 : siswa dengan pemahaman kosakata tinggi yang belajar dengan Think Pair Share

A1B2 : siswa dengan pemahaman kosakata rendah yang belajar dengan Think Pair Share

A2B1 : siswa dengan pemahaman kosakata tinggi yang belajar dengan Jigsaw

A2B2 : siswa yang pemahaman kosakata rendah yang belajar dengan Jigsaw

Menurut Sugiyono (2008: 61) "populasi adalah wilayah generalisasi yang terdiri atas obyek atau subyek yang mempunyai kualitas dan karakteristik tertentu yang diterapkan oleh peneliti untuk dipelajari dan kemudian ditarik kesimpulan". Populasi merupakan jumlah keseluruhan dari unit analisa yang ciricirinya akan diduga. Berdasarkan pengertian ini, maka dapat disimpulkan bahwa populasi dalam penelitian ini masuk ke dalam kategori populasi terbatas. Yaitu populasi yang memiliki sumber daya yang jelas batasbatasnya secara kuantitatif.

Pemilihan populasi dalam penelitian ini di antaranya, MA Nihayatul Amal Rawamerta dan MA Al Kautsar Cilamaya. Penelitian ini mengambil $\mathrm{N} \geq 500$ siswa dari kedua Madrasah Aliyah tersebut. (Arikunto (2013: 174) mengatakan bahwa sampel adalah sebagian atau wakil populasi yang diteliti. Jumlah sampel yang diambil adalah mengacu pada pendapat Arikunto bahwa untuk penelitian deskriptif disarankan besaran sampel antara 10\% sampai 25\% dari populasi terjangkau. Dengan maksud untuk mendapatkan data-data tentang variabel penelitian yang lebih lengkap dan akurat, penulis menerapkan ukuran atas jumlah sampel yaitu sekitar 80 orang dari seluruh populasi dengan menggunakan teknik proporsional random sampling. 
INFERENCE: Journal of English Language Teaching

Vol. 3, No. 1, April - July 2020

p-ISSN: 2615-8671

e-ISSN: 2615-868X

Tabel 2

Kisi-kisi Tes Penguasaan Kosakata

\begin{tabular}{|c|c|c|c|}
\hline No. & Subject & Indicator & Number \\
\hline 11 & Word Classes & Student is able to find the right word classes & $\begin{array}{c}1,3,4,5,7,11,13, \\
16,24,26,27,29\end{array}$ \\
\hline 22 & Word Families & $\begin{array}{c}\text { Student is able to find the correct words related } \\
\text { to derivatives form }\end{array}$ & 14,15 \\
\hline 33 & $\begin{array}{c}\text { Word } \\
\text { Formation }\end{array}$ & $\begin{array}{c}\text { Student is able to find the correct words related } \\
\text { to blending forms }\end{array}$ & $2,8,10$ \\
\hline 44 & $\begin{array}{c}\text { Multi-word } \\
\text { units }\end{array}$ & $\begin{array}{c}\text { Student is able to find the correct words related } \\
\text { to phrasal words and idioms }\end{array}$ & $17,18,19,23$ \\
\hline 5 & $\begin{array}{c}\text { Collocations } \\
5\end{array}$ & $\begin{array}{c}\text { Student is able to choose the grammatical } \\
\text { patterns which are related to collocation }\end{array}$ & $9,20,12$ \\
\hline 66 & $\begin{array}{c}\text { a. Synonyms } \\
\text { - Student is able to find the words which } \\
\text { have the similar meaning } \\
\text { - Student is able to choose the words } \\
\text { which have the opposite meaning }\end{array}$ & $6,21,22,28$ \\
\hline 77 & Homonyms & $\begin{array}{c}\text { Student is able to find the correct words related } \\
\text { to the homonym }\end{array}$ & 30 \\
\hline
\end{tabular}

Tabel 3

Kisi-kisi Tes Pemahaman Membaca

\begin{tabular}{|c|c|c|c|}
\hline NNo. & Subject & Indicator & Number \\
\hline 1 & recalling word & $\begin{array}{l}\text { Students are able to find meaning of a } \\
\text { word }\end{array}$ & $1,5,10,18,24$ \\
\hline 2 & $\begin{array}{l}\text { Drawing inferences } \\
\text { about a meaning of a } \\
\text { word in context }\end{array}$ & $\begin{array}{l}\text { Students are able to make inferences of a } \\
\text { word in context }\end{array}$ & $2,11,25,29$ \\
\hline 3 & $\begin{array}{l}\text { finding answer to } \\
\text { questions answered } \\
\text { explicitly or in } \\
\text { paraphrase }\end{array}$ & $\begin{array}{l}\text { Students are able to find answers } \\
\text { explicitly or in paraphrase }\end{array}$ & $3,6,14,19,21$ \\
\hline 4 & $\begin{array}{l}\text { weaving together ideas } \\
\text { in the content }\end{array}$ & $\begin{array}{c}\text { Students are able to generate ideas in the } \\
\text { content }\end{array}$ & $7,13,20,27$ \\
\hline 5 & $\begin{array}{l}\text { drawing inferences from } \\
\text { the content }\end{array}$ & $\begin{array}{l}\text { Students are able to draw inferences } \\
\text { from the content }\end{array}$ & $12,26,30$ \\
\hline 6 & $\begin{array}{l}\text { recognizing a writer's } \\
\text { purpose, attitude, tone, } \\
\text { or mood }\end{array}$ & $\begin{array}{c}\text { Students are able to recognize a writer's } \\
\text { purpose, attitude, tone, or mood }\end{array}$ & $8,15,22,28$ \\
\hline 7 & $\begin{array}{c}\text { identifying a writer's } \\
\text { technique }\end{array}$ & $\begin{array}{c}\text { Students are able to identify a writer's } \\
\text { technique }\end{array}$ & 9,16 \\
\hline 8 & $\begin{array}{l}\text { following the structure of } \\
\text { a passage }\end{array}$ & $\begin{array}{l}\text { Students are able to follow the structure } \\
\text { of a passage }\end{array}$ & $4,17,23$ \\
\hline
\end{tabular}

\section{Hasil dan Pembahasan}

\section{Deskripsi Data}

Berdasarkan data di atas diperoleh data bahwa untuk Pemahaman membaca bahasa inggris siswa menggunakan Think pair share dengan penguasaan kosakata tinggi terdapat 20 siswa memiliki rata - rata sebesar 84,25 dengan standar deviasi sebesar 6,935 dan untuk Pemahaman membaca bahasa inggris siswa menggunakan Think pair share dengan penguasaan kosakata rendah terdapat 20 siswa memiliki rata - rata sebesar 76,75 dengan standar deviasi sebesar 8,156. 
Tabel 4

Data Rangkuman Deskripsi

Descriptive Statistics

Dependent Variable: Pemahaman Membaca Bahasa Inggris

\begin{tabular}{|cc|c|c|c|}
\hline $\begin{array}{c}\text { Metode Pembalajaran } \\
\text { Kooperatif }\end{array}$ & Penguasaan Kosakata & Mean & Std. Deviation & $\mathrm{N}$ \\
\hline \multirow{3}{*}{ Think Pair Share } & Tinggi & 84,25 & 6,935 & 20 \\
& Rendah & 76,75 & 8,156 & 20 \\
& Total & 80,50 & 8,382 & 40 \\
Jigsaw & Tinggi & 86,75 & 6,544 & 20 \\
& Rendah & 87,50 & 8,192 & 20 \\
& Total & 87,12 & 7,328 & 40 \\
Total & Tinggi & 85,50 & 6,775 & 40 \\
& Rendah & 82,12 & 9,733 & 40 \\
& Total & 83,81 & 8,503 & 80 \\
\hline
\end{tabular}

Untuk Pemahaman membaca bahasa inggris siswa menggunakan Jigsaw dengan penguasaan kosakata tinggi terdapat 20 siswa memiliki rata - rata sebesar 85,75 dengan standar deviasi sebesar 6,544 dan untuk Pemahaman membaca bahasa Inggris siswa menggunakan jigsaw dengan penguasaan kosakata rendah terdapat 20 siswa memiliki rata - rata sebesar 87,50 dengan standar deviasi sebesar 8,192

\section{Data Pemahaman Membaca Bahasa Inggris siswa yang menggunakan Metode Think Pair share dengan Penguasaan Kosakata Tinggi}

Tabel 5

Pemahaman Membaca Bahasa Inggris siswa yang menggunakan Metode Think Pair share dengan Penguasaan Kosakata Tinggi

\begin{tabular}{|c|c|c|}
\hline \multicolumn{3}{|c|}{ Statistics } \\
\hline \multicolumn{3}{|c|}{$\begin{array}{l}\text { Pemahaman Membaca Bahasa Inggris siswa yang menggunakan Metode Think } \\
\text { Pair share dengan Penguasaan Kosakata Tinggi. }\end{array}$} \\
\hline \multirow[t]{2}{*}{$\mathbf{N}$} & Valid & 20 \\
\hline & Missing & 60 \\
\hline \multicolumn{2}{|c|}{ Mean } & 84,25 \\
\hline \multicolumn{2}{|c|}{ Median } & 85,00 \\
\hline \multicolumn{2}{|c|}{ Mode } & 80 \\
\hline \multicolumn{2}{|c|}{ Std. Deviation } & 6,935 \\
\hline \multicolumn{2}{|c|}{ Minimim } & 70 \\
\hline \multicolumn{2}{|c|}{ Maximum } & 95 \\
\hline
\end{tabular}

Data Pemahaman Membaca bahasa Inggris siswa yang menggunakan metode Think pair share dengan penguasaan kosakata tinggi diperoleh dari responden dengan sampel penelitian sebanyak 20 siswa yaitu nilai rata - rata sebesar 84,25 , median sebesar 85,00 , modus sebesar 80 , standar deviasi sebesar 6,935 , nilai terendah sebesar 70 dan nilai tertinggi sebesar 95. Bila dilihat dari hasil perhitungan di atas, maka bisa dikatakan bahwa pemahaman membaca bahasa Inggris siswa yang menggunakan metode think pair share dengan penguasaan kosakata tinggi pada MA Swasta di Karawang tergolong baik, hal ini diindikasikan dengan perolehan nilai rata - rata sebesar 84,25 . Untuk memperjelas data di atas dijelaskan dalam histogram berikut ini: 


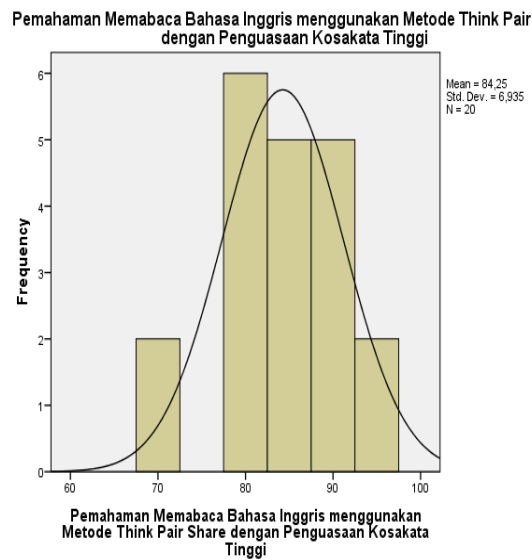

Gambar 1. Pemahaman Membaca Bahasa Inggris siswa yang menggunakan Metode think pair share dengan Penguasaan kosakata tinggi

Dari Gambar 1, maka dapat disimpulkan bahwa kemampuan membaca bahasa Inggris siswa yang menggunakan metode think pair share dengan penguasaan kosakata tinggi memiliki sebaran yang normal.

2. Data Pemahaman Membaca Bahasa Inggris siswa yang menggunakan Metode Think Pair share dengan Penguasaan Kosakata Rendah.

Tabel 6

Pemahaman Membaca Bahasa Inggris siswa yang menggunakan Metode Think Pair share dengan Penguasaan Kosakata Rendah

\begin{tabular}{|c|c|c|}
\hline \multicolumn{3}{|c|}{ Statistics } \\
\hline \multicolumn{3}{|c|}{$\begin{array}{c}\text { Pemahaman Membaca Bahasa Inggris } \\
\text { siswa yang menggunakan Metode Think } \\
\text { Pair share dengan Penguasaan Kosakata } \\
\text { Rendah }\end{array}$} \\
\hline \multirow[t]{2}{*}{$\mathbf{N}$} & Valid & 20 \\
\hline & Missing & 60 \\
\hline \multicolumn{2}{|c|}{ Mean } & 76,75 \\
\hline \multicolumn{2}{|c|}{ Median } & 80,00 \\
\hline \multicolumn{2}{|c|}{ Mode } & 80 \\
\hline \multicolumn{2}{|c|}{ Std. Deviation } & 8,156 \\
\hline \multicolumn{2}{|c|}{ Minimum } & 60 \\
\hline \multicolumn{2}{|c|}{ Maximum } & 90 \\
\hline
\end{tabular}

Data Pemahaman Membaca bahasa Inggris siswa yang menggunakan metode Think pair share dengan penguasaan kosakata rendah diperoleh dari responden dengan sampel penelitian sebanyak 20 siswa yaitu nilai rata-rata sebesar 76,75, median sebesar 80,00, modus sebesar 80 , standar deviasi sebesar 8,156 , nilai terendah sebesar 60 dan nilai tertinggi sebesar 90. Bila dilihat dari hasil perhitungan di atas, maka bisa dikatakan bahwa pemahaman membaca bahasa inggris siswa yang menggunakan metode think pair share dengan penguasaan kosakata rendah pada MA Swasta di Karawang tergolong baik, hal ini diindikasikan dengan perolehan nilai rata - rata sebesar 76,75 . Untuk memperjelas data di atas dijelaskan dalam histogram berikut ini: 


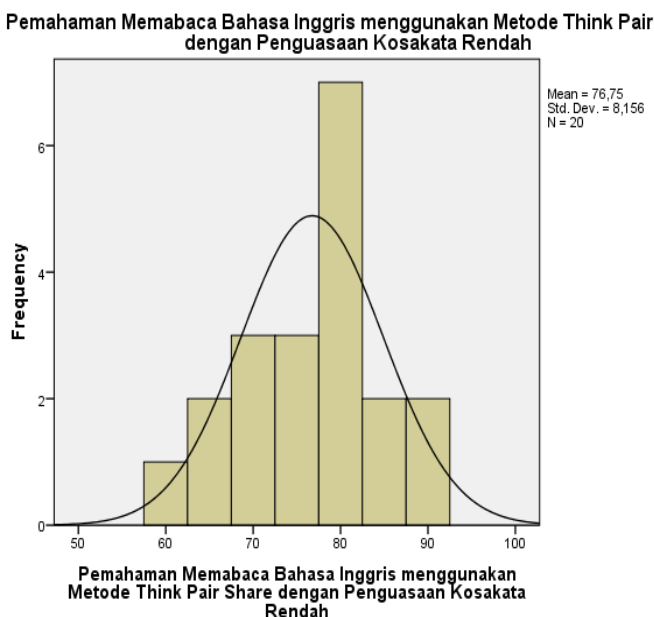

Gambar 2 Pemahamam Membaca Bahasa Inggris siswa yang menggunakan Metode think pair share dengan Penguasaan kosakata Rendah.

Dari histogram di atas dapat disimpulkan bahwa kemampuan membaca bahasa Inggris siswa yang menggunakan metode think pair share dengan penguasaan kosakata rendah memiliki sebaran yang normal.

\section{Data Pemahaman Membaca Bahasa Inggris siswa yang menggunakan Metode jigsaw dengan Penguasaan Kosakata Tinggi}

Tabel 7

Pemahaman Membaca Bahasa Inggris siswa yang menggunakan Metode jigsaw dengan Penguasaan Kosakata Tinggi

\begin{tabular}{|c|c|c|}
\hline \multicolumn{3}{|c|}{ Statistics } \\
\hline \multicolumn{3}{|c|}{$\begin{array}{l}\text { Pemahaman Membaca Bahasa Inggris siswa yang menggunakan Metode jigsaw } \\
\text { dengan Penguasaan Kosakata Tinggi. }\end{array}$} \\
\hline \multirow[t]{2}{*}{$\mathbf{N}$} & Valid & 20 \\
\hline & Missing & 60 \\
\hline Mean & & 86,75 \\
\hline Median & & 85,00 \\
\hline Mode & & 80 \\
\hline Std. Deviation & & 6,544 \\
\hline Minimim & & 80 \\
\hline Maximum & & 95 \\
\hline
\end{tabular}

Data Pemahaman Membaca bahasa Inggris siswa yang menggunakan metode jigsaw dengan penguasaan kosakata tinggi diperoleh dari responden dengan sampel penelitian sebanyak 20 siswa yaitu nilai rata-rata sebesar 86,75, median sebesar 85,00, modus sebesar 80, standar deviasi sebesar 6,544, nilai terendah sebesar 80 dan nilai tertinggi sebesar 95. Bila dilihat dari hasil perhitungan di atas, maka bisa dikatakan bahwa pemahaman membaca bahasa inggris siswa yang menggunakan metode jigsaw dengan penguasaan kosakata tinggi pada MA Swasta di Karawang tergolong baik, hal ini diindikasikan dengan perolehan nilai rata-rata sebesar 86,75. Untuk memperjelas data di atas dijelaskan dalam histogram berikut ini: 


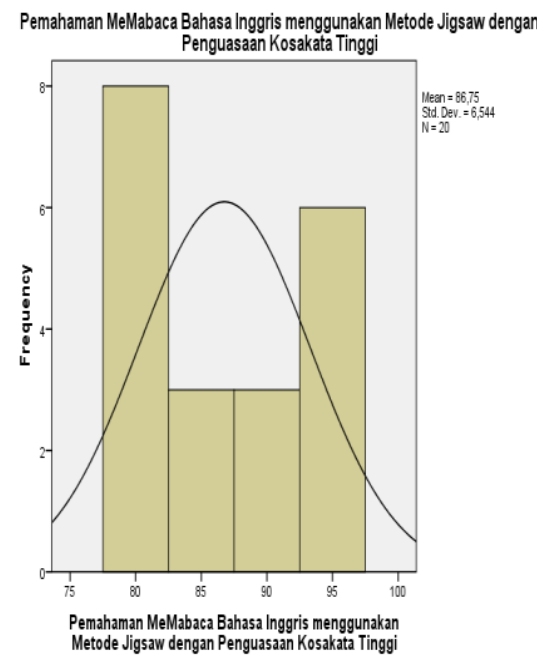

Gambar 3 Pemahaman Membaca Bahasa Inggris siswa yang menggunakan Metode jigsaw dengan Penguasaan kosakata tinggi.

Dari histogram di atas dapat disimpulkan bahwa kemampuan membaca bahasa Inggris siswa yang menggunakan metode jigsaw dengan penguasaan kosakata tinggi memiliki sebaran yang normal.

\section{Data Pemahaman Membaca Bahasa Inggris siswa yang menggunakan Metode jigsaw dengan Penguasaan Kosakata rendah}

Tabel 8

Pemahaman Membaca Bahasa Inggris siswa yang menggunakan Metode jigsaw dengan Penguasaan Kosakata rendah

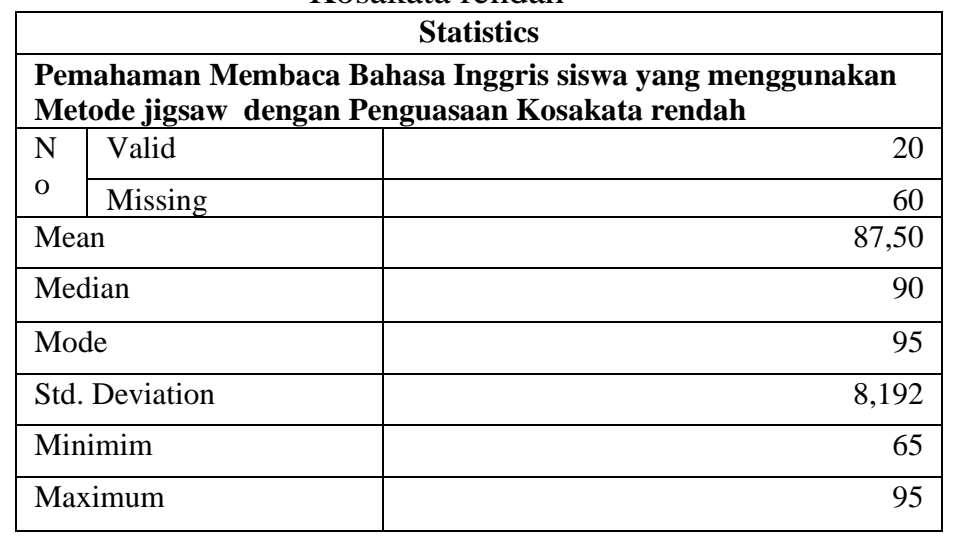

Data Pemahaman Membaca bahasa Inggris siswa yang menggunakan metode jigsaw dengan penguasaan kosakata rendah diperoleh dari responden dengan sampel penelitian sebanyak 20 siswa yaitu nilai rata rata sebesar 87,50, median sebesar 90,00, modus sebesar 80, standar deviasi sebesar 8,192 nilai terendah sebesar 65 dan nilai tertinggi sebesar 95. Bila dilihat dari hasil perhitungan di atas, maka bisa dikatakan bahwa pemahaman membaca bahasa inggris siswa yang menggunakan metode jigsaw dengan penguasaan kosakata rendah pada MA Swasta di Karawang tergolong baik, hal ini diindikasikan dengan perolehan nilai rata - rata sebesar 87,50. Untuk memperjelas data di atas dijelaskan dalam histogram berikut ini: 


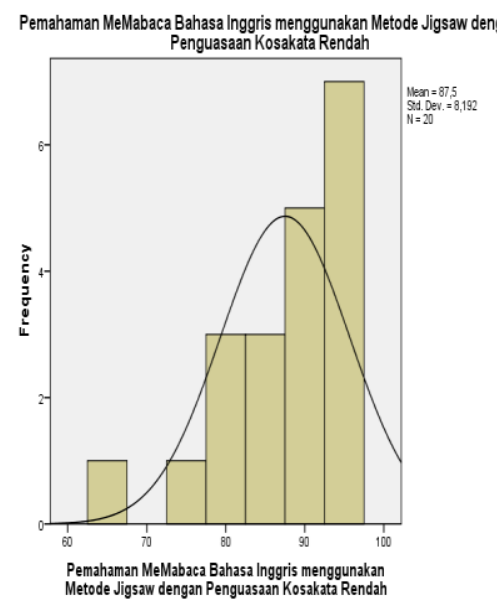

Gambar 4 Pemahaman Membaca Bahasa Inggris siswa yang menggunakan Metode jigsaw dengan Penguasaan kosakata rendah.

Dari histogram di atas dapat disimpulkan bahwa kemampuan membaca bahasa Inggris siswa yang menggunakan metode jigsaw dengan penguasaan kosakata rendah memiliki sebaran yang normal. Data hasil penelitian berupa Pemahaman Membaca bahasa Inggris siswa (Y) sebagai akibat dari perlakukan penelitian, yaitu perlakuan penelitian ini masing-masing memiliki level. Perlakuan penelitian pertama adalah $\left(\mathrm{X}_{1}\right)$, yaitu metode pembelajaran kooperatif (A) dengan miliki dua level yaitu Metode Think Pair share $\left(\mathrm{A}_{1}\right)$ dan Metode jigsaw $\left(\mathrm{A}_{2}\right)$, serta $\left(\mathrm{X}_{2}\right)$ penguasaan kosakata $(\mathrm{B})$ sebagai perlakuan ke dua dengan memiliki dua level yaitu penguasaan kosakata tinggi $\left(B_{1}\right)$, dan penguasaan kosakata rendah $\left(B_{2}\right)$. Data hasil penelitian dianalisis dengan teknik statistik deskriptif, untuk mengukur tendensi sentral dan tendensi penyebaran data dari setiap kelompok perlakuan. Perhitungan data hasil penelitian dilakukan dengan menggunakan program olah data yaitu SPSS 2.4.

\section{Pengujian Persyaratan Analisis}

Tabel 9

Hasil Perhitungan Uji Normalitas Data

One-Sample Kolmogorov-Smirnov Test

\begin{tabular}{|c|c|c|}
\hline & & $\begin{array}{c}\text { Pemahaman Menbaca } \\
\text { Bahasa Inggris }\end{array}$ \\
\hline \multicolumn{2}{|c|}{$\mathrm{N}$} & 80 \\
\hline \multirow{2}{*}{$\begin{array}{c}\text { Normal } \\
\text { Parameters }\end{array}$} & Mean & 83,81 \\
\hline & Std. Deviation & 8,503 \\
\hline \multirow{2}{*}{$\begin{array}{l}\text { Most Extreme } \\
\text { Differences }\end{array}$} & Absolute & ,164 \\
\hline & $\begin{array}{l}\text { Positive } \\
\text { Negative }\end{array}$ & $\begin{array}{l}, 136 \\
-, 164\end{array}$ \\
\hline \multicolumn{2}{|c|}{ Kolmogorov-Smirnov Z } & 1,471 \\
\hline \multicolumn{2}{|c|}{ Asymp. Sig. (2-tailed) } & , 156 \\
\hline
\end{tabular}

a. Test distribution is Normal.

b. Calculated from data.

Dari di atas menunjukkan bahwa semua kelompok data yang diuji normalitasnya dengan uji KolmogorvSmirnov dengan SPSS20 memberikan nilai yang signifikansi dengan nilai 0,156 > 0,05. Dengan demikian disimpulkan bahwa delapan kelompok data dalam penelitian ini berasal dari populasi yang berdistribusi normal. Hal ini menunjukkan bahwa salah satu prasyarat uji $\mathrm{F}$ dalam penelitian telah terpenuhi. 
Tabel 10

Hasil Uji Homogenitas

Levene's Test of Equality of Error Variances ${ }^{a}$

Dependent Variable: Pemahaman Membaca Bahasa Inggris

\begin{tabular}{|c|c|c|c|}
\hline$F$ & $\mathrm{df} 1$ & $\mathrm{df} 2$ & Sig. \\
\hline, 361 & 3 & 76 &, 781 \\
\hline
\end{tabular}

Tests the null hypothesis that the error variance of the dependent variable is equal across groups.

a. Design: Intercept $+A+B+A * B$

Persyaratan bahwa data homogenitas nilai signifikan hitung > nilai signifikan $(0,05)$ maka hipotesis nol $\left(\mathrm{H}_{0}\right)$ diterima sesuai persyaratan. Hasil uji homogenitas diperoleh nilai Sig 0,781 , yang berarti nilai Sig 0,781>0,05. Maka dapat disimpulkan bahwa data pemahaman membaca bahasa Inggris siswa memiliki variansi populasi yang sama atau dengan kata lain data seluruh kelompok perlakuan berasal dari populasi yang homogen.

Tabel 11

Hasil Perhitungan Skor pemahaman membaca Bahasa Inggris Siswa

Statistics

\begin{tabular}{|c|c|c|c|c|}
\hline & A1B1 & A1B2 & A2B1 & A2B2 \\
\hline Valid & 20 & 20 & 20 & 20 \\
\hline Missing & 60 & 60 & 60 & 60 \\
\hline Mean & 84,25 & 76,75 & 86,75 & 87,50 \\
\hline Median & 85,00 & 80,00 & 85,00 & 90,00 \\
\hline Mode & 80 & 80 & 80 & 95 \\
\hline Std. Deviation & 6,935 & 8,156 & 6,544 & 8,192 \\
\hline Skewness &,- 493 &,- 309 & 208 & $-1,237$ \\
\hline Std. Error of Skewness & ,512 & ,512 & ,512 & ,512 \\
\hline Kurtosis & 103 &,- 359 & $-1,776$ & 1,476 \\
\hline Std. Error of Kurtosis & 992 & ,992 & ,992 & 992 \\
\hline Range & 25 & 30 & 15 & 30 \\
\hline Minimum & 70 & 60 & 80 & 65 \\
\hline Maximum & 95 & 90 & 95 & 95 \\
\hline
\end{tabular}

Keterangan:

A1B1: Pemahaman Membaca Bahasa Inggris siswa yang menggunakan Metode Think Pair share dengan Penguasaan Kosakata Tinggi,

A1B2: Pemahaman Membaca Bahasa Inggris siswa yang menggunakan Metode Think Pair share dengan Penguasaan Kosakata rendah

A2B1: Pemahaman Membaca Bahasa Inggris siswa yang menggunakan Metode jigsaw dengan Penguasaan Kosakata TinggiA2B2: Pemahaman Membaca Bahasa Inggris siswa yang menggunakan Metode jigsaw dengan Penguasaan Kosakata rendah 
Tabel 12

Hasil Uji Hipotesis

Tests of Between-Subjects Effects

Dependent Variable: Pemahaman Membaca Bahasa Inggris

\begin{tabular}{|l|r|r|r|r|r|}
\hline Source & $\begin{array}{r}\text { Type III Sum of } \\
\text { Squares }\end{array}$ & df & Mean Square & \multicolumn{1}{c|}{ F } & Sig. \\
\hline Corrected & 1445,938 & 3 & 481,979 & 8,586 &, 000 \\
Model & 561962,813 & 1 & 561962,813 & 10010,940 &, 000 \\
Intercept & 877,813 & 1 & 877,813 & 15,638 &, 000 \\
A & 227,813 & 1 & 227,813 & 4,058 &, 047 \\
B & 340,313 & 1 & 340,313 & 6,062 &, 016 \\
A ${ }^{*}$ B & 4266,250 & 76 & 56,135 & & \\
Error & 567675,000 & 80 & & & \\
Total & 5712,188 & 79 & & & \\
Corrected & & & & \\
Total & & & & \\
\hline
\end{tabular}

a. $\mathrm{R}$ Squared $=, 253$ (Adjusted R Squared $=, 224$ )

- Pengaruh Metode Pembelajaran Kooperatif Terhadap pemahaman Bacaan Bahasa Inggris Siswa.

- Hipotesis 1:

Ho; $\mu \mathrm{A} 1=\mu \mathrm{A} 2=$ Tidak terdapat pengaruh metode pembelajaran Kooperatif terhadap pemahaman membaca bahasa inggris siswa.

$\mathrm{H} 1 ; \mu \mathrm{A} 1 \neq \mu \mathrm{A} 2=$ Terdapat pengaruh metode pembelajaran Kooperatif terhadap pemahaman membaca bahasa inggris siswa.

Berdasarkan hasil pengujian pada Tabel Test of Between-Subject Effect di atas yang merupakan tabel utama yang mempresentasikan hasil hipotesis yang diajukan peneliti. Dari tabel tersebut, diketahui nilai sig untuk variabel metode pembelajaran kooperatif adalah $0,000<0,05$ dan $F_{\text {hitung }}=15,638$, maka Ho ditolak dan H1 diterima. Simpulannya terdapat pengaruh yang signifikan metode pembelajaran kooperatif terhadap Pemahaman membaca bahasa Inggris siswa. Dengan demikian hipotesis pertama diterima.

\section{- Pengaruh Penguasaan Kosakata Terhadap Pemahaman Bacaan Bahasa Inggris}

- Hipotesis 2 :

$\mathrm{H} 0: \mu \mathrm{B} 1=\mu \mathrm{B} 2$;

$\mathrm{H} 1: \mu \mathrm{B} 1 \mu \mathrm{B} 2$

Artinya

Ho; $\mu \mathrm{B} 1=\mu \mathrm{B} 2=$ tidak terdapat Pengaruh Penguasaan Kosakata Terhadap pemahaman Membaca Bahasa Inggris Siswa.

$\mathrm{H} 1 ; \mu \mathrm{B} 1 \neq \mu \mathrm{B} 2=$ terdapat Pengaruh Penguasaan Kosakata Terhadap pemahaman Membaca Bahasa Inggris Siswa.

Berdasarkan hasil pengujian pada Tabel Test of Between-Subject Effect di atas yang merupakan tabel utama yang mempresentasikan hasil hipotesis yang diajukan peneliti. Dari tabel tersebut, diketahui nilai Sig untuk variabel penguasaan kosakata adalah $0,047<0,05$ dan $\mathrm{F}_{\text {hitung }}=4,058$, maka $\mathrm{H}_{\mathrm{o}}$ ditolak dan $\mathrm{H}_{1}$ diterima. Simpulannya terdapat pengaruh yang signifikan antara Penguasaan Kosakata Terhadap pemahaman bacaan Bahasa Inggris Siswa. Dengan demikian hipotesis kedua diterima.

- Terdapat Pengaruh Interaktif yang signifikan Metode Pembelajaran kooperatif dan penguasaan kosakata Terhadap pemahaman Bacaan Bahasa Inggris.

- Hipotesis 3 :

Ho; int $\mathrm{A} X$ int $\mathrm{B}=0$ Tidak Terdapat Pengaruh Interaktif yang signifikan Metode Pembelajaran kooperatif dan penguasaan kosakata Terhadap pemahaman membaca Bahasa Inggris Siswa.

$\mathrm{H} 1$; int $\mathrm{A} \mathrm{x}$ int $\mathrm{B} \neq 0 \quad$ Terdapat Pengaruh Interaktif yang signifikan Metode Pembelajaran kooperatif dan penguasaan kosakata Terhadap pemahaman membaca Bahasa Inggris Siswa. 


\section{INFERENCE: Journal of English Language Teaching}

Vol. 3, No. 1, April - July 2020

p-ISSN: 2615-8671

e-ISSN: 2615-868X

Berdasarkan hasil pengujian pada Tabel Test of Between-Subject Effect diperoleh nilai Sig untuk interaksi metode pembelajaran kooperatif dan penguasaan kosakata adalah 0,016<0,05 dan $F_{\text {hitung }}=6,062$, maka $\mathrm{H}_{\mathrm{o}}$ ditolak dan $\mathrm{H}_{1}$ diterima. Simpulannya terdapat pengaruh interaktif yang signifikan metode pembelajaran kooperatif dan penguasaan kosakata terhadap pemahaman bacaan bahasa Inggris siswa. Dengan demikian hipotesis ketiga diterima.

\section{Pembahasan}

Mengacu pada hasil penelitian dan didukung oleh analisis statistik untuk penelitian tentang pemahaman membaca bahasa inggris siswa, diperoleh kesimpulan bahwa data berasal dari populasi terdistribusi normal dan berasal dari varians yang sama (homogen). Dengan demikian data yang ada telah memenuhi uji persyaratan analisis data. Berdasarkan hal tersebut maka penelitian dapat dilanjutkan menuju pengujian hipotesis. Dari pengujian hipotesis tersebut dapat dianalisis bahwa:

\section{Terdapat Pengaruh metode Pembelajaran kooperatif Terhadap pemahaman bacaan bahasa inggris.}

Dari tabel tersebut, diketahui nilai Sig untuk variabel metode pembelajaran kooperatif adalah $0,000<$ 0,05 dan $\mathrm{F}_{\text {hitung }}=15,638>\mathrm{F}_{\text {tabel }}=0,361$, maka Ho ditolak dan $\mathrm{H} 1$ diterima. Kesimpulannya. terdapat pengaruh yang signifikan metode pembelajaran kooperatif terhadap Pemahaman membaca bahasa inggris siswa. Dengan demikian hipotesis pertama diterima.

2. Terdapat Pengaruh penguasaan kosakata Terhadap pemahaman bacaan bahasa inggris.

Dari tabel tersebut, diketahui nilai Sig untuk variabel kecerdasan emosional adalah $0,047<0,05$ dan $\mathrm{F}_{\text {hitung }}=4,058>\mathrm{F}_{\text {tabel }}=0,361$, maka Ho ditolak dan H1 diterima. Kesimpulannya terdapat pengaruh yang signifikan antara Penguasaan Kosakata Terhadap pemahaman Membaca Bahasa Inggris Siswa. Dengan demikian hipotesis kedua diterima.

\section{Terdapat Pengaruh Interaktif yang signifikan metode Pembelajaran kooperatif dan penguasaan kosakata terhadap pemahaman bacaan bahasa inggris.}

Berdasarkan hasil pengujian pada Tabel Test of Between-Subject Effect diperoleh nilai Sig untuk interaksi metode pembelajaran kooperatif dan penguasaan kosakata adalah 0,16<0,05 dan $F_{\text {hitung }}=6,062>$ $\mathrm{F}_{\text {tabel }}=0,361$, maka Ho ditolak dan H1 diterima. Kesimpulannya terdapat pengaruh interaktif yang signifikan metode pembelajaran kooperatif dan penguasaan kosakata terhadap pemahaman membaca bahasa Inggris siswa. Dengan demikian hipotesis ketiga diterima. Hasil uji lanjut dengan uji Tukey diperoleh hasil sebagai berikut:

Tabel 12

Uji Lanjut

Multiple Comparisons

Dependent Variable: Pemahaman Menbaca Bahasa Inggris Tukey HSD

\begin{tabular}{|cc|c|c|c|c|c|}
\hline (I) Post Hoc & (J) Post Hoc & Mean & Std. Error & Sig. & \multicolumn{2}{|c|}{$95 \%$ Confidence Interval } \\
\cline { 7 - 7 } & & Difference (I-J) & & & Lower Bound & Upper Bound \\
\hline \multirow{4}{*}{ A1B1 } & A1B2 & $7,50^{*}$ & 2,369 &, 012 & 1,28 & 13,72 \\
& A2B1 & $-2,50$ & 2,369 &, 718 & $-8,72$ & 3,72 \\
& A2B2 & $-3,25$ & 2,369 &, 521 & $-9,47$ & 2,97 \\
\multirow{2}{*}{ A1B2 } & A1B1 & $-7,50^{*}$ & 2,369 &, 012 & $-13,72$ & $-1,28$ \\
& A2B1 & $-10,00^{*}$ & 2,369 &, 000 & $-16,22$ & $-3,78$ \\
& A2B2 & $-10,75^{*}$ & 2,369 &, 000 & $-16,97$ & $-4,53$ \\
A2B1 & A1B1 & 2,50 & 2,369 &, 718 & $-3,72$ & 8,72 \\
& A1B2 & $10,00^{*}$ & 2,369 &, 000 & 3,78 & 16,22 \\
& A2B2 &,- 75 & 2,369 &, 989 & $-6,97$ & 5,47 \\
& A1B1 & 3,25 & 2,369 &, 521 & $-2,97$ & 9,47 \\
A2B2 & A1B2 & $10,75^{*}$ & 2,369 &, 000 & 4,53 & 16,97 \\
& A2B1 &, 75 & 2,369 &, 989 & $-5,47$ & 6,97 \\
\hline
\end{tabular}

Based on observed means. The error term is Mean Square(Error) $=56,135$.

*. The mean difference is significant at the 0,05 level. 
Dalam penelitian ini perlu mendalami penggunaan metode kooperatif dalam pemahaman bahasa inggris siswa yang harus dikembangkan dengan pengamatan lebih mendalam pada siswa yang penguasaan kosakata tinggi dan penguasaan kosakata rendah. Untuk penggunaan metode kooperatif ini umumnya siswa lebih dituntut untuk berpikir lebih keras untuk itu perlu dikembangkan inovasi kedua metode ini yang lebih menarik dan membuat rasa ingin tahu peserta didik. Dengan ketertarikan ini siswa akan mengembangkan kognitif dengan cara mengembangkan daya nalar.

a. Pada kelompok A1B1 dan A1B2 terlihat bahwa Mean Difference sebesar 10,00 artinya selisih antara rata-rata kelompok A1B1 dan A1B2 sebesar 10,00. Nilai ini cukup besar dan dapat dibuktikan dengan nilai signifikansi $0,000<0,05$, atau dapat diartikan bahwa khusus untuk kelompok A1, terdapat perbedaan yang signifikan pemahaman bacaan bahasa inggris antara kelompok B1 dan B2.

b. Pada kelompok A1B1 dan A2B1 terlihat bahwa Mean Difference sebesar -0,75, artinya selisih antara rata-rata kelompok A1B1 dan A2B1 sebesar -0,75. Nilai ini cukup kecil dan dapat dibuktikan dengan nilai signifikansi $0,718<0,05$, atau dapat diartikan bahwa khusus untuk kelompok B1, terdapat perbedaan yang signifikan pemahaman bacaan bahasa inggris antara kelompok A1 dan A2.

c. Pada kelompok A1B2 dan A2B2 terlihat bahwa Mean Difference sebesar -7,50, artinya selisih antara rata-rata kelompok A1B2 dan A2B2 sebesar -10,75. Nilai ini cukup kecil dan dapat dibuktikan dengan nilai signifikansi $0,000>0,05$, atau dapat diartikan bahwa khusus untuk kelompok B2, terdapat perbedaan yang signifikan pemahaman bacaan bahasa inggris antara kelompok A1 dan A2.

d. Pada kelompok A2B1 dan A2B2 terlihat bahwa Mean Difference sebesar -0,75 artinya selisih antara rata-rata kelompok A2B1 dan A2B2 sebesar -0,75. Nilai ini cukup kecil dan dapat dibuktikan dengan nilai signifikansi 0,989 > 0,05, atau dapat diartikan bahwa khusus untuk kelompok A2, tidak terdapat perbedaan yang signifikan pemahaman bacaan bahasa inggris antara kelompok B1 dan B2.

\section{Simpulan}

Terdapat pengaruh yang signifikan metode pembelajaran kooperatif terhadap pemahaman bacaan bahasa Inggris siswa Madrasah Aliyah Swasta di Karawang. Hal ini dibuktikan dengan nilai Sig 0,000< 0,05 , dengan $F_{\text {hitung }}=15,638$. Selanjutnya, terdapat pengaruh yang signifikan penguasaan kosakata terhadap pemahaman bacaan bahasa Inggris siswa Madrasah Aliyah Swasta di Karawang. Hal ini dibuktikan dengan nilai Sig $0,047<0,05$, dengan $F_{\text {hitung }}=4,058$. Yang terakhir, terdapat pengaruh interaktif yang signifikan metode pembelajaran kooperatif dan penguasaan kosakata terhadap pemahaman bacaan bahasa Inggris siswa Madrasah Aliyah Swasta di Karawang. Hal ini dibuktikan dengan nilai Sig 0,016<0,05, dengan F hitung $=6,062$.

\section{Daftar Rujukan}

Alderson. (2000). Assessing Reading. Cambridge: Cambridge University Press.

Arends. (2009). Cooperative Learning. Bandung: Grasindo.

Arikunto, S. (2002) Prosedur penelitian suatu pendekatan praktek. Jakarta: Rineka Cipta.

Blachowicz \& Ogle, (2008). Language, Arts, \& Disciplines. New York: Guilford Press.

Fraenkel \& Norman. (2003). How to Design and Evaluate Research in Education. New York: McGrawHill Companies.

Gillies \& Ashman, A. F. (2003). Cooperative Learning: The Social and Intellectual Outcomes of Learning in Groups. London and New York: Routledge Falmer.

Hajar, I. (1996). Dasar - dasar metodologi penelitian kuantitatif dalam pendidikan, Jakarta. PT. Raja Grafindo

Hamalik, O. (2006). Proses Belajar Mengajar. Jakarta: PT. Bumi Aksara.

Harmer, J. (2007). How to teach vocabulary. Essex: Longman.

Hornby, (2000). Oxford Advanced Learners of Current English. New York: Oxford University Press. 
INFERENCE: Journal of English Language Teaching

Vol. 3, No. 1, April - July 2020

p-ISSN: 2615-8671

e-ISSN: $2615-868 \mathrm{X}$

Komalasari, K. (2003). Pembelajaran Kontekstual : Konsep dan Aplikasi. Bandung: PT. Refika Adiatama.

Nurgiantoro, B. (1987). Penilaian Dalam Pelajaran Bahasa Dan Sastra. Yogyakarta : BPEE.

Rahayu. T. S. (1999). Proses Pembentukan kosakata. Yogyakarta: UNY Press.

Riyanto, Y. (2010). Metodologi Penelitian Pendidikan. Surabaya: Penerbit SIC.

Rusman. (2012). Model-model pembelajaran, Jakarta : PT. Raja Grafindo persada

Sagala, S. (2009). Konsep dan Makna Pembelajaran: Untuk Membantu Memecahkan Problematika Belajar dan Mengajar. Bandung: CV. Alfabeta.

Sedarmayanti, (2002). Metodologi Penelitian. Bandung: Mandar Maju.

Sugiyono, (2008). Metode Penelitian Kuantitatif Kualitatif dan R\&D. Bandung: Alfabeta.

Suprikono, A. (2010). Cooperative Learning. Yogyakarta: Pustaka Media.

Slavin, R. E. (2010). Cooperative Learning Teori, Riset dan Praktik. Bandung: Nusa Media.

Tabrani, A. R. (1989). Pendekatan Dalam Proses Belajar Mengajar. Bandung: Remadja Karya.

Tarigan, H. G. (1986). Menulis Sebagai Suatu Keterampilan Membaca. Bandung: Angkasa.

Tim pengembangan MKDP. (2011). Kurikulum pembelajaran, Bandung: PT Rajawali pers.

Trianto. (2007). Model-model Pembelajaran Inovatif Berorientasi Kontruktivistik. Jakarta: Prestasi Pustaka.

Triyanto. (2010). Model pembelajaran terpadu. Jakarta: PT. Bumi Aksara. 